Scientific Journal Warsaw University of Life Sciences - SGGW

Problems of World Agriculture volume 17 (XXXII), number 4, 2017: 228-235

DOI: 10.22630/PRS.2017.17.4.99

Agnieszka Parlińska ${ }^{1}$, Maria Parlińska ${ }^{2}$

Warsaw University of Life Sciences - SGGW

\title{
The Crop Insurance Systems in Poland Towards the EU
}

\begin{abstract}
The increasing number of unfavorable conditions of agricultural production causes the farmers to suffer severe losses in their activity. At the same time, the increase in the profitability of agricultural production, the support of numerous European Union funds, led to increased interest in insurance as an instrument supporting agricultural risk management. Hence, both the agricultural industry and the insurance industry see the need to create an effective agricultural and livestock insurance system.

The paper examines the changes and scope of crop insurance in Poland towards the European Countries. There were presented issues connecting to policies, regulation and state aid rules, crop insurance level in EU countries and characteristic of the crop insurance market - case study Poland. There was used descriptive and comparative methods, as well as the selected statistical method. The analysis was performed in the years 2005-2016.
\end{abstract}

Keywords: crop insurance, subsidies, risk

JEL Classification: G0, G2, Q1

\section{Introduction}

Agricultural production is threatened by a number of risk factors affecting both the asset and the farm income. These include risks primarily related to production such as weather conditions, pests and plant diseases, market conditions, etc. As a consequence of these factors, the stability of agricultural incomes may be shaken. In recent years, the European Union has considered the possible integration of agricultural risk management systems within the Common Agricultural Policy, and also analyzes crisis management systems to better prepare for emergencies in the agricultural sector (Risk Management Tools for EU Agriculture, 2011; Iturrioz, 2009; Józefecka, 2009).

Most European Union countries have a classic insurance system, mainly one and several types of risk insurance and also crop-yield insurance. These are generally private insurance. The exception to this is Greece and Cyprus where insurance is public and mandatory. In many countries, the crop insurance market represents 2 or 3 insurance companies. The level of development of the agricultural insurance system in a given country depends mainly on the level of risk that varies from country to country and from the public financial support for the insurance system (CEA, 2005; Clipici, Frant, 2013).

\footnotetext{
${ }^{1} \mathrm{PhD}$, Department of Finance, Faculty of Economic Sciences, WULS-SGGW, ul. Nowoursynowska 166, 02-787 Warszawa, e-mail: agnieszka parlinska@sggw.pl; https://orcid.org/0000-0001-6640-3097

2 Doctor habilitated, professor of the WULS-SGGW, Department of Agricultural Economics and International Economic Relations, Faculty of Economic Sciences WULS-SGGW, ul. Nowoursynowska 166, 02-787 Warszawa, e-mail: maria_parlinska@sggw.pl; https://orcid.org/0000-0003-3323-7779
} 
The role of government is different in different countries. Some offer or subsidize insurance, while others can count on help only if risk is realized. Help is provided through a compensation system, targeted funds or so-called. Future markets, which may be partially funded by the rural community in an optional or mandatory manner. The following analysis will present the various existing risk management tools. This will allow us to better understand the evolution of insurance systems in Europe, as the development of insurance systems depends very precisely on the presence of other risk management tools, the role of the public sector and, in particular, the existence of ad hoc relief measures (Agricultural insurance schemes, 2008b).

\section{Material and methods}

The aim of this paper is to examine the changes and scope of crop insurance among the European Countries (EU). The following problems are examined: policies, regulation and state aid rules, crop insurance level in EU countries and characteristic of the crop insurance market - case study Poland.

The analyses, carried out in the paper, cover the period of 2006- 2015. The information and data about analyzed issues are taken from the applicable legislation, the Ministry of Agriculture and Rural Development (MARD) and the Central Statistical Office (GUS). The data used illustrates the examined problems, shows the scale of changes, their tendency and differences.

The descriptive and comparative methods were used in the research paper, as well as the selected statistical method in order to analyze the problem from the economic point of view.

\section{Policies, regulations and state aid rules}

Crisis definitions and catastrophes eligible for state aid in the Member States of the European Union have been verified and compared in the "Community Guidelines for State Aid in the Agriculture Sector" (EC 2000). Further Commission Directives (EC 2006b) and Regulation (EC 2006a) on the application of Articles 87 and 88 of the Treaty were adopted in December 2006. The definitions were largely formulated on the basis of World Trade Organization (WTO) agreements. Member States' experts have defined the terms of the disaster and the emergency situation eligible for state aid and the definition of insured risk, if any. Some states refuse public assistance where the risk has been realized can be insured. Such countries include Spain, Austria, Portugal, Greece, Sweden, Turkey and Italy for insurance subsidized by the state budget and in France if the insurance has reached the assumed level of diffusion. Since 2010, the regulation partially makes the conditions for state aid subject to the purchase of a specific agricultural insurance (CEA, 2005; Clipici, Frant, 2013).

Most EU Member States follow certain Community Guidelines on State Aid (EC, 2000) when deciding whether or not a state can assist. Member States can be classified in four groups according to the degree of compliance with EU guidelines. For the first group of countries in their legislation strictly followed the above mentioned guidelines, the second group has adopted certain assumptions without mentioning the guidelines in its legislation. 
The third group adopted stricter assumptions than those provided for in the Community Rules. On the other hand, the fourth group of countries defined their assumptions less restrictively than was assumed in the EU guidelines (EC, 2001; Agricultural insurance schemes, 2008b).

\section{Crop insurance statistics in EU countries}

In 2006, about $23 \%$ of the crop value of 27 EU Member States was insured. Insurance amounted to $€ 1583$ million, i.e. $4 \%$ of the declared value. Spain, considered the most developed country in the area of insurance systems, in the world, accounts for $€ 564$ million, with only 5.86 million hectares being insured, indicating a relatively low market penetration ( $26 \%$ of the area), compared to Germany, where market penetration is much higher ( 7.26 million hectares, i.e. $43 \%$ of crop area), while the average amount of premiums is 129 million euros. This fact can be explained by the fact that in Germany insurance usually only covers one risk (hail). On the other hand, high value in Spain can be explained by the greater number of dangers covered and potentially higher risk in this country (Clipici, Frant, 2013).

The total amount of the grant was 497 million euros, representing $32 \%$ of the sum insured. In each country, the amount of subsidies varies greatly. The highest subsidy amounts in Europe were registered in Italy and Portugal, for example in Italy $80 \%$ of crop insurance guarantees. In other countries such as UK, the subsidy is not applied at all. Average amount of damage, i.e. the total sum of compensation paid by insurance companies for a specified number of years a year divided by the total amount of contributions from the same period - is in the range of 60 to $70 \%$ (Agricultural insurance schemes, 2008a).

\section{Characteristic of the crop insurance market - case study Poland}

The increasing number of unfavorable conditions of agricultural production causes the farmers to suffer severe losses in their activity. At the same time, the increase in the profitability of agricultural production, the support of numerous European Union funds, led to increased interest in insurance as an instrument supporting agricultural risk management. Hence, both the agricultural industry and the insurance industry see the need to create an effective agricultural and livestock insurance system. However, it is necessary to combine the actions of the state and insurance companies (Parlińska, 2011; Józefecka, 2009).

The answer to the market demand was the agricultural insurance law introduced by the Act of 7 July 2005 on agricultural and livestock insurance. However, the experience of 2006 and subsequent years prompted the legislator to make changes in the scope of the insurance subjects and range of risks (Table 1). At the moment the crop insurance contract covers: cereals, maize, rape, colza, hops, tobacco, ground vegetables, fruit trees and shrubs, strawberries, potatoes, sugar beet or legumes, sown or harvested for harvest, grown in the main crop, The law allows to insure from all the risks specified by the law (package insurance) or selected by the agricultural producer.

Also, the upper limits of the sum of the compulsory insurance of crops constitute the sum insured, however they should not exceed the limits designated by the Minister for Agriculture. The sum of the crop insurance is influenced by the following factors (Parlińska, 2011; Wicka, 2009): 
- the surface of all the fields (parcels), on which the agricultural cultivation has been reported to the insurance,

- the amount of the yield obtained in the holding in question,

- the market price per unit yield of the main, the gross price specified in the cultivation contract (if yield is subject to contract),

- documented the value of planting trees, shrubs, strawberries, or the average value recorded in the area at the time of the conclusion of the insurance contract.

Table 1. The changes in the scope of the insurance subject and range of the risks in Poland

\begin{tabular}{|c|c|c|c|c|}
\hline & \multicolumn{4}{|c|}{ Changes in the Act of Law of agricultural crop and livestock insurance } \\
\hline & From 7.07.2005 & From 27.04.2006 & From 7.03.2007 & $\begin{array}{c}\text { From } 25.07 .2008 \text { till } \\
\text { now }\end{array}$ \\
\hline $\begin{array}{l}\text { Scope of } \\
\text { the } \\
\text { insurance } \\
\text { subject }\end{array}$ & $\begin{array}{l}\text { cereals, maize, } \\
\text { rape, colza, potatoes, sugar } \\
\text { beet }\end{array}$ & $\begin{array}{l}\text { added: hops, } \\
\text { vegetables, } \\
\text { fruit trees and } \\
\text { shrubs }\end{array}$ & $\begin{array}{l}\text { added: tobacco, } \\
\text { strawberry, legumes, } \\
\text { changes in the names: } \\
\text { instead vegetables - } \\
\text { ground vegetables, }\end{array}$ & \\
\hline $\begin{array}{l}\text { Range of } \\
\text { risks }\end{array}$ & $\begin{array}{l}\text { From sowing or planting to } \\
\text { harvest: fire, hurricane, } \\
\text { flood, wet, hail, lightning, } \\
\text { explosion, landslide, } \\
\text { avalanche, drought, } \\
\text { negative effects of } \\
\text { wintering, spring frosts }\end{array}$ & $\begin{array}{l}\text { excluded: fire, } \\
\text { explosion }\end{array}$ & $\begin{array}{l}\text { changes in definitions } \\
\text { of: hurricane, } \\
\text { lightning, drought, } \\
\text { negative effects of } \\
\text { wintering, spring } \\
\text { frosts }\end{array}$ & $\begin{array}{l}\text { changes in definitions } \\
\text { of: spring frosts; } \\
\text { liability for partial } \\
\text { damage caused by } \\
\text { frosts from } 15 \text { April }\end{array}$ \\
\hline
\end{tabular}

Source: Regulations the Minister of agriculture and rural development on the maximum sum for each of the insurance of crops and livestock from 2008-2015.

Table 2. Changes in maximum of insurance's sum in crop insurance contracts in Poland in the years 2008-2016

\begin{tabular}{|c|c|c|c|c|c|c|c|c|c|}
\hline \multirow{2}{*}{ Description } & \multicolumn{9}{|c|}{ The maximum total coverage } \\
\hline & 2008 & 2009 & 2010 & 2011 & 2012 & 2013 & 2014 & 2015 & 2016 \\
\hline for cereals & \multicolumn{4}{|c|}{6000} & 8000 & 8100 & 8400 & & 14000 \\
\hline for maize & 6000 & 11000 & 13000 & 10000 & 10000 & 9000 & 8800 & & 10300 \\
\hline $\begin{array}{l}\text { for rape and } \\
\text { turnip rape }\end{array}$ & \multicolumn{4}{|c|}{6000} & 10000 & 12300 & 9200 & & 10550 \\
\hline for hops & 25000 & 30000 & \multicolumn{2}{|c|}{40000} & 26000 & 36700 & 37300 & & 45500 \\
\hline for tobacco & 30000 & \multicolumn{3}{|c|}{35000} & 21000 & 26500 & 24100 & & 26100 \\
\hline for vegetables & \multicolumn{2}{|c|}{162000} & \multicolumn{3}{|c|}{129000} & 83000 & 144000 & & 182400 \\
\hline $\begin{array}{l}\text { for trees and } \\
\text { shrubs }\end{array}$ & \multicolumn{2}{|c|}{84000} & \multicolumn{3}{|c|}{61000} & 55600 & 59200 & & 101500 \\
\hline for strawberries & \multicolumn{2}{|c|}{25000} & \multicolumn{4}{|c|}{50000} & 43200 & & 52000 \\
\hline for potatoes & 16000 & 17500 & 2500 & & 000 & 32200 & 35700 & & 31200 \\
\hline for sugar beet & \multicolumn{2}{|c|}{8000} & \multicolumn{3}{|c|}{9000} & 12200 & 10400 & & 11430 \\
\hline for legumes & \multicolumn{5}{|c|}{15000} & 15600 & 16700 & & 20130 \\
\hline
\end{tabular}

Source: see table 1 . 


\section{A. Parlińska, M. Parlińska}

According to the Act of Law the sum of the insurance shall be determined in agreement with the agriculture producer at a level which cannot be higher than this which are established by regulation. The changes of insurance's sum and level of the aid for contribution in crop insurance contracts in the years 2008-2016 are presented in Table 2 and Table 3.

Table 3. Changes in the level of the aid for contribution of the insurance contracts in Poland in the years 2006-2016

\begin{tabular}{|c|c|c|c|c|}
\hline \multirow{2}{*}{ Description } & \multicolumn{4}{|c|}{ The value of the aid } \\
\hline & 2006 & till 06.2007 & From 06.2007 till 23.04 .2015 & From 24.04.2015 \\
\hline for cereals & \multirow{3}{*}{$40 \%$} & \multirow{3}{*}{$40 \%$} & \multirow{11}{*}{$50 \%$} & \multirow{11}{*}{$\begin{array}{l}\text { Till } 65 \% \text {, } \\
\text { but insurance } \\
\text { premium should be: } \\
-3.5 \% \text { of the insured } \\
\text { sum for cereals, } \\
\text { maize, spring rape, } \\
\text { colza, potatoes or } \\
\text { sugar beet }-5 \% \text { of } \\
\text { insured sum for } \\
\text { winter rape, } \\
\text { vegetables g round, } \\
\text { hop, tobacco, trees } \\
\text { and bushes fruit, } \\
\text { strawberries or } \\
\text { legumes }\end{array}$} \\
\hline for maize & & & & \\
\hline for rape and turnip rape & & & & \\
\hline for hops & & $35 \%$ & & \\
\hline for tobacco & & - & & \\
\hline for vegetables & - & $35 \%$ & & \\
\hline for trees and shrubs & & & & \\
\hline for strawberries & & - & & \\
\hline for potatoes & \multirow{2}{*}{$35 \%$} & \multirow{3}{*}{$35 \%$} & & \\
\hline for sugar beet & & & & \\
\hline for legumes & - & & & \\
\hline
\end{tabular}

Source: Regulations the Minister of Agriculture and Rural Development on the maximum sum for each of the insurance of crops and livestock from 2008-2015.

The potential of crop insurance can be assessed by looking into the agricultural area and sown. In 2009, agricultural area in Poland was more than 15.5 million ha, of which about $74 \%$ is the sown area. In the following years, can be observed decline in the agricultural area and drilling, which in the year 2015 were 14.6 million hectares and the total sown area was 10.7 million ha. Also, during the research time could noticed that about $30 \%$ of the sown area was a subject to of obligatory insurance (Fig. 1).

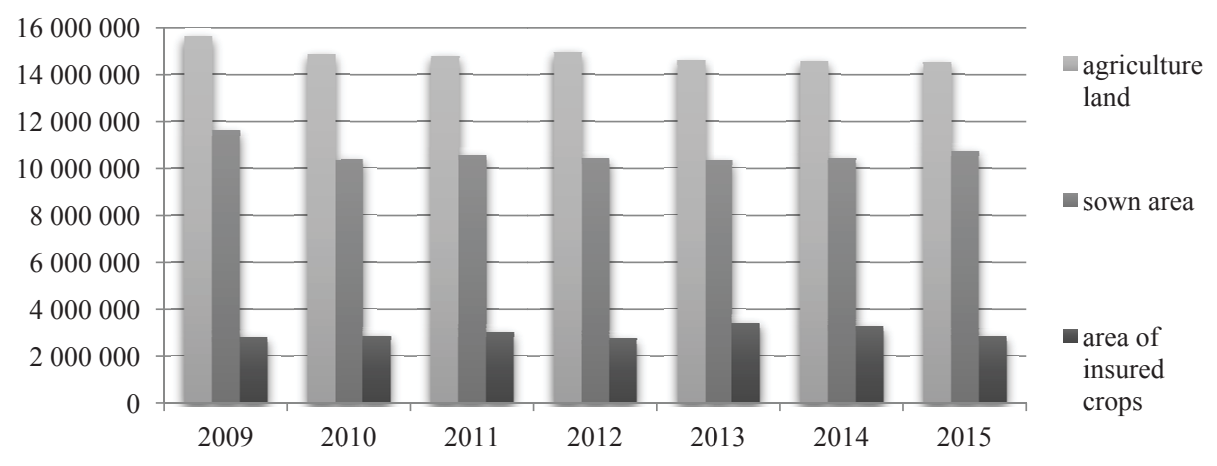

Fig. 1. The total area of agricultural land in Poland in years 2009-2015 (in hectares)

Source: own calculation on the base of data of the Central Statistical Office. 
Over the years, can be noted a general decline in agricultural area in Poland. The biggest decreases in the area over the years 2009-2015 can be observed in crops of potatoes- $50 \%$, hops $-30 \%$ and vegetable $-25 \%$. The increases were observed for maize for grain $-144 \%$. This trend has to do with the general downward trend of the utilized agricultural area, and in the case of potatoes from the droughts that are extremely unfavourable for crops of potatoes and make farmers abandon their crops to other plants (Table 4)

Table 4. The area insured crops

\begin{tabular}{l|rrrrr}
\hline \multicolumn{1}{c|}{ Specification } & 2010 & 2011 & 2013 & 2014 & 2015 \\
\hline Area of insured crops & & & in thous. ha & \\
cereals & 2845.78 & 3032.63 & 3398.81 & 3269.87 & 2823.61 \\
rape & 1697.97 & 1691.06 & 1922.49 & 1741.33 & 1568.26 \\
maize & 829.05 & 995.99 & 1056.44 & 997.19 & 787.81 \\
potatoes & 200.53 & 174.08 & 276.23 & 363.92 & 299.85 \\
sugar beets & 15.76 & 15.93 & 14.43 & 25.23 & 17.14 \\
pulse crops & 41.47 & 48.84 & 46.60 & 60.34 & 48.95 \\
fruit from berry & 30.86 & 20.06 & 21.65 & 34.27 & 62.79 \\
plantations and fruit trees & 7.88 & 53.15 & 8.09 & 9.93 & 13.04 \\
field vegetables & 10.99 & 26.64 & 12.28 & 18.55 & 16.05 \\
\hline
\end{tabular}

Source: own calculation on the base of data of the Central Statistical Office.

The development of the agricultural insurance market with state subsidies to premiums in Poland was launched in 2006 when the legal provisions of the Act of 7 July 2005 on farm and livestock insurance came into force. The average area for one policy is about 20 hectares and it did not change significantly in 2009-2015. Thus, the large and very large farms are insured. The higher average premium results not only from the coverage of larger areas, but also (as shown by research carried out by Poznan University of Economics) from the tendency of large farms to insure against a greater number of risks. Therefore it can be seen that not all farmers are insured despite the obligation to insure at least $50 \%$ of the crop area and at the same time do not use the full potential of the funds that could be mobilized to finance these insurance. Farmers usually insure themselves from the hail, and risks such as drought and floods are very low. It was also found that finding reinsurance coverage especially at drought risk was limited or impossible. In addition, there was a significant problem associated with a vague interpretation of the drought risk definition. Hence, after receiving signals from both insurance companies and agricultural circles, targeted subsidies were introduced to cover some of the compensation paid to agricultural producers for damage caused by drought. In the years of this change, insurers received a payment of 88.2 million zloty after the drought in 2008. In recent years the most common risks in the crop insurance policy include: negative effects of wintering, hail and spring frosts. The disaster was 2012, when insurance companies suffered a great deal of damage as a result of unfavorable weather conditions compared to previous years.

A farmer wishing to use agricultural subsidies is obliged to conclude an insurance contract with the selected insurance company who has signed an agreement with the Ministry of Agriculture of insurance or any other insurance business. Among the insurers who have the right to offer agricultural insurance with state subsidies, the largest share in 
the sale, both in the amount and value of these policies, holds the largest Polish property company PZU S.A.. However, since 2006, the share of PZU S.A. in favor of Concordia Polska Towarzystwo Ubezpieczeń.

Table 5. Characteristic of the implementation of subsidized crop insurance in Poland in 2009-2015

\begin{tabular}{|c|c|c|c|c|c|c|c|}
\hline Specification & 2009 & 2010 & 2011 & 2012 & 2013 & 2014 & 2015 \\
\hline $\begin{array}{l}\text { Number of } \\
\text { insurance policies }\end{array}$ & 144080 & 149751 & 139772 & 137863 & 151101 & 142292 & 139108 \\
\hline $\begin{array}{l}\text { The insurance sum } \\
\text { (billion PLN) }\end{array}$ & 6.49 & 7.84 & 10.24 & 12.09 & 14.23 & 13.33 & 13.69 \\
\hline $\begin{array}{l}\text { Area of insured } \\
\text { crops (ha) }\end{array}$ & 2808104.3 & 2845777.5 & 3032633.7 & 2751438.6 & 3398811.8 & 3269870.9 & 2823606.3 \\
\hline $\begin{array}{l}\text { The average sum of } \\
\text { insurance per ha }\end{array}$ & 2311.3 & 2756.3 & 3376.1 & 4393.0 & 4187.4 & 4075.7 & 4850.2 \\
\hline $\begin{array}{l}\text { The average sum of } \\
\text { insurance per policy } \\
\text { (PLN) }\end{array}$ & 45047.1 & 52379.0 & 73252.1 & 87674.7 & 94190.3 & 93659.2 & 98449.2 \\
\hline $\begin{array}{l}\text { The average area } \\
\text { per policy }\end{array}$ & 19.5 & 19.0 & 21.7 & 20.0 & 22.5 & 23.0 & 20.3 \\
\hline $\begin{array}{l}\text { Value of the aid } \\
\text { (mln PLN) }\end{array}$ & 79.1 & 97.0 & 126.6 & 162.5 & 164.3 & 161.5 & 173.4 \\
\hline $\begin{array}{l}\text { The average aid per } \\
\text { policy (PLN) }\end{array}$ & 549.2 & 648.0 & 905.5 & 1178.8 & 1087.7 & 1134.7 & 1246.3 \\
\hline
\end{tabular}

Source: own calculation on the base of data of the Central Statistical Office on data from the Ministry of Agriculture and Reginal Development Department of Finance.

According to the data of the Ministry of Agriculture and Rural Development, the scope of insurance covered by the subsidy covers mainly crops (their share in the structure of contracts concluded and the value of subsidies is about 95\%). In 2013 over 151 thousand. The policy of crops with subsidies from the state budget, which means almost 14 times their growth against 11 thousand. policy in 2006.

In 2006, under 10738 agricultural insurance contracts were covered little more than 300 thousand hectares of crops. In 2015 more than 2.8 million of hectares of crops are insured within 139108 insurance contracts. However, the biggest increase in the market could be observed in 2008 when it was obliged to insure at least $50 \%$ of the crop area. In 2010, the Ministry of Agriculture and Rural Development subsidized 300 million PLN, 131 million PLN in 2009 and 150 million PLN two years earlier. According to the MARD data, in 2015 insurance premiums amounted to PLN 173.4 million, which represents more than 17 times increased against PLN 9.85 million in 2006 (Table 4).

\section{Conclusion}

Crop insurance systems in European countries differ in terms of both the available insurance products and the state's share in shaping agricultural insurance policies. This is dependent on many factors such as the level of economic development, the frequency of natural disasters and the structure of the agricultural sector in a given country. The high level of variation in the nature of agricultural production and the crop insurance market in these countries demonstrates how difficult it would be to have a common crop insurance 
policy across the European Union. At the same time, existing loss-making insurance schemes in countries such as Canada and the United States are waiting for their momentum in Europe, where none of the countries so far have offered farmers such a form of hedging.

The agricultural insurance market with state subsidies has been operating in Poland since 2006. After the first years of existing the legal norms of the Act on agricultural and farm livestock insurance were subject to changes in the subject matter, construction of contributions, maximum sums of insurance or subsidies from the state budget. Significant changes took place in 2008, when the obligation to insure at least $50 \%$ of the crop area was introduced. The number, value and area of crops covered by the agricultural insurance contracts with subsidies are visible from year to year. However, in spite of the above changes, farmers do not use the resources allocated by the resort for this purpose. At the same time, the insurer reports that the insurance cover is taken up by large and mediumsized households, for whom weather risks can cause financial distress. Small farms, despite the state subsidy system, still have little need to secure their crops.

A number of risks threatening agricultural management force agricultural entrepreneurs to take preventive actions in case of realization of risks. Changes introduced in the crop insurance system have so far indicated that the focus was mainly on increasing the prevalence of agricultural producers' participation. This is evidenced by the introduction of an insurance obligation in 2008 or continued pressure to increase the level of subsidized insurance.

\section{Literature}

Agricultural insurance schemes (2008a). The current agricultural risk management systems in the EU and Candidate Countries, European Comission.

Agricultural insurance schemes (2008b). Policies for disaster aids and for risk management in agriculture, European Commission.

CEA (2005). European Insurance system for agricultural risks, CEA document AGR5037, (06/05). Agricultural Risks Insurance Committee, Paris.

Clipici, E., Frant, F. (2013). The Evolution of Agricultural Insurance Market. Lucrări Ştiințifice, Seria I, $15(3), 1-$

EC (2001). Risk Management Tools for EU Agriculture, with a special focus on insurance. Directorate General Agriculture. Accessed from: http://ec.europa.eu/agriculture/publi/insurance/index en.htm.

Dmochowski, S. (1989). Ubezpieczenia majątkowe w rolnictwie. Poradnik, PWE, Warszawa.

Iturrioz, R. (2009). Agricultural Insurance, Primer series on insurance issue 12, The World Bank. Accessed from: www.worldbank.org/nbfi.

Hęćka, A., Łyskawa, K. (2013). Ubezpieczenia upraw rzepaku od skutków złego przezimowania; uwarunkowania środowiskowe i ekonomiczne. Zeszyty Naukowe SGGW Problemy Rolnictwo Światowego, 13(1), 24-36.

Klimkowski, C. (2002). Istota, skutki i zarządzanie ryzykiem katastroficznym w rolnictwie polskim, Studia i Monografie Instytut Ekonomiki Rolnictwa i Gospodarki Żywnościowej, Warszawa.

Józefecka, M., Tetwejer, U. (2009). Ubezpieczenia od ryzyka wystapienia klęsk żywiołowych w polskim rolnictwie na tle ustawodawstwa unijnego. Wiadomości Ubezpieczeniowe, 1, 171-183.

Parlińska, A. (2011). Funkcjonowanie ubezpieczeń upraw rolnych i zwierząt gospodarskich z dopłatami. Roczniki Naukowe SERIA, 13(1), 278-282.

Wicka, A. (2009). Ocena wartości rynku obowiązkowych ubezpieczeń upraw w rolnictwie polskim w świetle ustawy o dopłatach do ubezpieczeń upraw rolnych i zwierzat gospodarskich. ACTA Scientiarum Polonorum Oeconomia, 8(1), 103-109.

Risk Management Tools for EU Agriculture - Dyrekcji Generalnej ds. Rolnictwa Komisji Europejskiej, 2011. Accessed from: http://ec.europa.eu/agriculture/publi/insurance/text en.pdf.

Rocznik Statystyczny GUS 2006 - 2016

Ustawa z dnia 7 lipca 2005 r. o ubezpieczeniach upraw rolnych i zwierzat gospodarskich (Dz. U. Nr 150 z dnia 9 sierpnia 2005 r., z późn.zm.). 